\title{
Measuring Marketing Performance: A Review and A Framework
}

\author{
Yuhui Gao, \\ Marketing Group, Dublin City University Business School, \\ Glasnevin, Dublin 9, Ireland. Telephone: +353 1 7006936; Fax: + 3531 7005446; \\ E-mail: $\underline{\text { Yuhui.Gao@dcu.ie }}$
}

\section{To cite this article:}

Gao, Y. (2010). Measuring marketing performance: a review and a framework, The Marketing Review, 2010, Vol. 10, No. 1, pp. 25-40. doi: 10.1362/146934710X488924 


\title{
Measuring Marketing Performance: A Review and A Framework
}

\begin{abstract}
Critics of marketing commonly allude to problems with its accountability and credibility. In order to address these issues, marketing professionals have been called on to demonstrate the contribution of marketing to firm performance. A better understanding of current research in marketing performance can better enable marketing managers to justify its expense. Given the foregoing, it was determined to (1) review the current status of marketing performance studies, and (2) develop a comprehensive, yet concise model to measure the performance of marketing. To begin, the main terms used in marketing performance are clarified. Then, a detailed review of marketing performance studies is provided. An integrated Model for Measuring Marketing Performance (MMMP) is then proposed. Finally, some conclusions are drawn and some directions for future research are suggested.
\end{abstract}

Keywords: Marketing performance measurement, marketing metrics, literature review

\section{Biography}

Yuhui Gao is a lecturer in Marketing at Dublin City University Business School. Her current research interests are in the measurement of marketing performance (marketing metrics), marketing research, and firm leaders' personal values and their relevance to marketing strategy. Her work has appeared in the Journal of Strategic Marketing and Industrial Marketing Management.

Telephone: +353 1 7006936; Fax: + 3531 7005446;

E-mail: Yuhui.Gao@dcu.ie 


\section{INTRODUCTION}

Marketing professionals are under ever-increasing pressure to justify their firms' expenditure on marketing. Researchers in marketing have cautioned that the inability of marketing to demonstrate its contribution to firm performance has weakened its standing within firms (Ambler \& Roberts 2008; O'Sullivan \& Abela 2007; Stewart 2008). In order to save marketing from this crisis of confidence, there have been a number of significant calls for more research into the measurement of marketing performance (e.g., Bolton 2004; Lehmann 2004). Such research has been continuously ranked as a top priority by the Marketing Science Institute (2002, 2004, 2006)

Rust et al. (Rust, Ambler, Carpenter, Kumar, \& Srivastava 2004, p.76) stated powerfully that: "The effective dissemination of new methods of assessing marketing productivity to the business community will be a major step toward raising marketing's vitality in the firm and, more important, toward raising the performance of the firm itself". Therefore, a better understanding of the assessment of marketing performance could help marketing practitioners to quantify their contribution to the financial performance of firms. In the service of contributing to such understanding, this paper has the following research objectives:

1. To review the current status of marketing performance studies.

2. To develop a comprehensive yet concise model for measuring marketing performance. 
The remainder of the paper is structured as follows. Firstly, the main terminology used in marketing performance is clarified. Then, the synthesised inter-relationships that exist between the key concepts are illustrated. Next, a detailed review of marketing performance studies is provided. A general trend is identified, and the existing studies that are related to marketing performance are categorised. Using this review of marketing performance research, an integrated Model for Measuring Marketing Performance (MMMP) is then proposed. Finally, some limitations of the research are presented and discussed, and conclusions are drawn.

\section{CONCEPTUAL FOUNDATION AND CLARIFICATION}

A review of the literature has shown the interchangeable, sometimes even conflicting use of key concepts such as marketing effectiveness, marketing efficiency, marketing productivity, marketing performance, and marketing metrics. Such indiscriminate use of these key terms has led to significant confusion in the basic concepts involved. For example, Weber (2002) considers the concept 'marketing productivity' to be concerned with effectiveness, whereas Clark (2000) and Morgan et al. (2002) consider the concept to be concerned with efficiency. Other researchers have noted that the terms 'marketing efficiency' and 'marketing effectiveness' are used interchangeably (e.g. Connor \& Tynan 1999). In order to promote clarity and precision of usage and to explain how the term 'marketing performance' is used throughout this paper, the use of the concepts mentioned above is reviewed and analysed. 
Marketing effectiveness: Drucker (1974, p.45) considers effectiveness to be doing the right thing. In the organisational literature, effectiveness is considered from the perspective of the extent to which a certain performance achieves the goals of the organisation (Clark 2000). Similarly, in the marketing literature, marketing effectiveness is described as the extent to which marketing actions have helped the company to achieve its business goals (Ambler, Kokkinaki, Puntoni, \& Riley 2001).

Marketing effectiveness has attracted a great deal of attention in academic and managerial circles (e.g. Appiah-Adu, Fyall, \& Singh 2001; Dunn, Norburn, \& Birley 1994; Ghosh, Schoch, Taylor, Kwan, \& Kim 1994; Homburg, Grozdanovic, \& Klarmann 2007; Kotler 1977; Vorhies \& Morgan 2003). According to Connor and Tynan (1999), the majority of studies of marketing effectiveness have relied essentially on the use of one or more of three key approaches developed by Kotler (1977), Hooley and Lynch (1985) and Carson (1990).

Marketing efficiency: In order to clarify the distinction between effectiveness and efficiency, Drucker (1974, p.45) states that: "Effectiveness is the foundation of success - efficiency is the minimum condition for survival after success has been achieved. Efficiency is concerned with doing things right. Effectiveness is doing the right things". Thus, efficiency is concerned with the outcomes of business programmes in relation to the resources employed in implementing them (Walker \& Ruekert 1987). More specifically, efficiency concerns the relation between the results of marketing (marketing output) to the effort and resources put into marketing (marketing input), with the aim of maximising the former relative to the latter (Bonoma \& Clark 1988). The literature on this topic uses a wide variety of methods to measure input (e.g. 
marketing expenses, knowledge and technology, man-hours) and output (e.g. sales, profit, services, cash flow).

Marketing productivity: Sevin (1965) was one of the first to entertain and develop the concept of productivity in the marketing discipline. The terms that are used in relation to marketing productivity are borrowed from elementary physics, where productivity equals the ratio of the effect yielded to the energy expended (Sevin 1965). From a marketing perspective, Sevin (1965, p.9) defines marketing productivity as "the ratio of sales or net profits (effect produced) to marketing costs (energy expended) for a specific segment of the businesses".

Although various conceptual and operational definitions of marketing productivity have been proposed, no consensus has been achieved (Sheth \& Sisodia 2002). Marketing productivity has been considered from a range of different perspectives. It was traditionally viewed primarily in terms of efficiency (e.g. Sheth and Sisodia 1995). Much of the early work on marketing productivity made use of distribution cost analysis or functional-cost accounting (e.g. Alderson 1948; Cox 1948; Feder 1965; Parker 1962).

The traditional view of marketing productivity has improved our understanding of the identification and measurement of both the costs of marketing and the revenue that results from it (Morgan et al. 2002). It has, nevertheless, suffered from a number of serious problems with respect to concept and implementation (see Morgan et al. 2002 for a review). Firstly, any measure of efficiency depends upon knowledge of the causal relationships involved, in that it is these that link input with output. In fact, we 
generally have little knowledge of such relationships in marketing, and the nature of the transformations involved remains unclear. Secondly, productivity analysis tends to ignore the effect of the time lag between marketing input and the resulting change in output. Thirdly, productivity analysis places an emphasis on the amounts of marketing input and the resulting output, rather than on quality. Finally, marketing productivity analysis ignores other dimensions, such as effectiveness and adaptability. In addition to such conceptual limitations, marketing productivity analysis has one further serious flaw, in that it assumes that marketing input and the resulting output can be assessed both economically and accurately, and that such an assessment will remain stable over time.

Recently, the conceptualisation of marketing productivity has been broadened. For example, Sheth and Sisodia (2002) perceived marketing productivity from a customer-centric perspective by defining it as 'effective efficiency', i.e. marketing productivity should include dimensions of both efficiency and effectiveness. Ideally, the marketing function of a company should generate loyal and satisfied customers at low cost. However, it is all too often the case that companies either create satisfied customers at unacceptably high cost, or alienate customers in their quest for marketing efficiency.

In contrast to Sheth and Sisodia's (2002) approach, Rust et al. (2004) have advanced the traditional efficiency view of marketing productivity by introducing the concept of the 'chain of marketing productivity'. This is a model that relates the specific actions taken by the firm (i.e. the Marketing Action) to the overall condition and standing of the firm (i.e. The Firm). The model starts by considering the strategies used by the 
firm that could include promotion strategy, product strategy, or any other marketing or firm strategy. These strategies inform the tactical marketing actions of the firm, such as advertising campaigns, efforts to improve service improvement, branding initiatives, loyalty programmes, and other specific initiatives designed to have an effect in the market. These tactical actions then influence customer satisfaction, attitudes toward the brand, loyalty, or other customer-centred attributes. For the firm, these measures may be aggregated to yield marketing assets, which may be measured by indicators such as brand quality, customer satisfaction, or customer equity. Customer behaviour thus influences the market, the changing market share of the company, and its sales. A firm's market position may thus be considered as being determined by that firm's marketing assets. The financial impact of marketing actions can be evaluated by a variety of methods, such as return on investment (ROI) or the economic value added (EVA). Publicly traded firms may also seek to increase their market value/capitalisation or shareholder value. The marketing productivity framework described herein extends the scope of a firm's marketing activities to its overall value. Marketing activities influence intermediate outcomes (the thoughts, feelings, knowledge, and ultimately the behaviour of customers), which in turn influence the firm's financial performance. Using this framework, it is possible to show how expenditure on marketing adds value for shareholders.

Marketing performance: It is somewhat surprising that a review of the literature has failed to unearth a clear and explicit definition of the term 'marketing performance', even though research on marketing performance is well established (AMA 1959; Feder 1965). Bonoma and Clark (1998, p.1) note that: “...perhaps no other concept in 
marketing's short history has proven as stubbornly resistant to conceptualization, definition, or application as that of marketing performance...".

The only consensus that has been reached in both the strategic (e.g. Chakravarthy 1986; Morgan \& Strong 2003) and marketing literature (e.g. Clark 2000; Clark \& Ambler 2001; Morgan, Clark, \& Gooner 2002; Vorhies \& Morgan 2003) is that marketing performance is multidimensional in nature. However, that which constitutes a superior marketing performance may differ between businesses (Vorhies \& Morgan 2003). Because the effectiveness and efficiency dimensions of performance may not converge and may even be inversely related in the short term (Bhargava, Dubelaar, \& Ramaswami 1994), firms tend to make important decisions that reflect a trade-off between emphasising either effectiveness or efficiency in the setting of their marketing goals and allocation of resources (Walker \& Ruekert 1987). Following on the approach used by Homburg (2007, p.21), marketing performance is herein defined as: “...the effectiveness and efficiency of an organization's marketing activities with regard to market-related goals, such as revenues, growth, and market share...”.

Ambler (2000) also points out a lack of precision in the terminology used to describe marketing performance. He proposes the adoption of the word 'metric' to capture a top-level measure of marketing performance (Shaw \& White 1999). The term 'marketing metrics' will now be discussed.

Marketing metrics: Ambler (2000, p.61) provides a detailed explanation of marketing metrics: 
" A 'metric' is a performance measure that top management should review. It is a measure that matters to the whole business. The term comes from music and implies regularity: the reviews should typically take place yearly or halfyearly. A metric is not just another word for measure - while all metrics are measures, not all measures are metrics. Metrics should be necessary, precise, consistent and sufficient (i.e. comprehensive) for review purposes. Metrics may be financial (usually from the profit and loss account), from the marketplace, or from non-financial internal sources (innovation and employee).”

The Marketing Science Institute (2004) defines marketing metrics as: “...the performance indicators top management use (or should use) to track and assess the progress - specifically the marketing performance - of a business or business unit."

In summary, some of the basic terminology of marketing, such as marketing effectiveness, marketing efficiency, marketing productivity, marketing performance and marketing metrics, has been the cause of considerable conceptual confusion in the literature. Given this confusion, the first objective of this paper was to discuss these concepts individually and to draw distinctions between them. Table 1 summarises the definitions of these concepts and the related literature.

---Insert Table 1 About Here---

These concepts must not be seen as being isolated from one other, rather they are highly inter-related. Using the review of the literature given above, some interrelationships between these terms may be seen, as illustrated in Figure 1. There is general agreement regarding the multidimensionality of marketing performance, with marketing efficiency and marketing effectiveness being two subcategories of the broader notion of marketing performance. The traditional view of marketing productivity is concerned primarily with the effect of efficiency on the marketing 
function (shown as the ............. line in Figure 1), but the modern view considers marketing productivity to include both marketing efficiency and marketing effectiveness (shown as the -..... line in Figure 1). As a result of these contrasting views, the term 'marketing productivity' will not be used in this study, in order to avoid confusion. Because the concept of marketing performance reflects its multidimensional character and has proved to be less controversial, the term 'marketing performance' will be used. O'Sullivan and Abela (2007) also adopted this term in their study of the relationship between marketing performance and firm performance.

--- Insert Figure 1 About Here ---

\section{A REVIEW OF MARKETING PERFORMANCE STUDIES}

This section starts with an identification of general trends in the use of marketing performance measures. A categorisation of studies related to marketing performance is then given. Finally an integrated Model for Measuring Marketing Performance (MMMP) is proposed.

\section{General trend of marketing performance measurement}

Although there is little consensus on how to measure marketing performance, some general trends may be identified from studies of marketing performance. Clark (1999) provided a review of the history of measuring the performance of marketing and suggested three shifts as shown in Figure 2. 
Firstly, there was a move from the use of financial to nonfinancial measures of output (shift No.1 in Figure 2). Early work on the measurement of marketing performance focused mainly on the financial measures of profit, sales (unit and value) and cash flow (Bonoma \& Clark 1988; Feder 1965; Sevin 1965). There is some unease about the use of financial measures to assess business performance, however (Eccles 1991). Traditional accounting systems have been criticised for the lack of consideration they give to long-term factors (Chakravarthy 1986). Newer, nonfinancial measures of output, such as customer satisfaction, customer loyalty, and brand equity have attracted considerable research interest (Clark 1999). Davidson (1999) also recognised the growing importance of nonfinancial measures of performance in his emphasis of the fact that intangible assets, such as brand, technology, competence and customer loyalty, have gradually become more important measures of corporate performance.

Secondly, there has been an expansion from the measurement of just the output yielded by marketing to measuring the marketing input as well (shift No. 2 in Figure 2). Marketing activities (input) such as marketing audit, marketing implementation, and market orientation lead to intermediate outcomes such as customer satisfaction, customer loyalty, and brand equity, which in turn lead to financial output. The intermediate outcomes may therefore be considered as marketing assets (Srivastava, Shervani, \& Fahey 1998) that may be used to produce superior financial performance.

Thirdly, there has been a gradual change in emphasis from the use of one-dimensional to the use of multidimensional measures of performance (shift No.3 in Figure 2). Bonoma and Clark (1988) and Walker and Ruekert (1987) suggested independently that the measurement of marketing performance should include the assessment of 
both marketing efficiency and marketing effectiveness. More researchers now agree that marketing performance is multidimensional (e.g. Ambler, Kokkinaki, \& Puntoni 2004; Vorhies \& Morgan 2003).

More recently, a new trend has appeared that links marketing performance to firm value, and in particular to shareholder value (shift No.4 in Figure 2) (Lehmann 2004; Luo \& Bhattacharya 2006; Luo \& Donthu 2006a; Rust, Ambler, Carpenter, Kumar, \& Srivastava 2004). This trend has emerged due to demands for marketing to have greater accountability and credibility (Luo \& Donthu 2006b; O'Sullivan \& Abela 2007; Stewart 2008). For marketing professionals truly to occupy an equal seat at the executive table, they must define and deliver quantitative measurements that demonstrate the contribution of marketing to the value of the firm (Lehmann 2004).

As a result of this requirement, the number and variety of measures that are available has increased. While companies rarely suffer from having too few measures (Kaplan \& Norton 1992), it has been suggested that marketing researchers should develop sets of measures that are small enough to be manageable but comprehensive enough to give an accurate evaluation of performance (Clark 1999). Figure 2 shows the general trend regarding the measurement of marketing performance measurement.

--- Insert Figure 2 About Here ---

\section{Categorising studies related to marketing performance}

According to O'Sullivan and Abela (2007), research on the measurement of marketing performance may be divided into three streams, namely (1) the 
measurement of marketing productivity (e.g., Rust, Ambler, Carpenter, Kumar, \& Srivastava 2004), (2) the identification of metrics in use (e.g., Ambler 2000; Barwise \& Farley 2004), and (3) the measurement of brand equity (e.g., Aaker \& Jacobson 2001; Ailawadi, Lehmann, \& Neslin 2003). However, this classification is incomplete and needs to be updated in order to incorporate more recent studies. For this reason, the study described herein provides a comprehensive review of studies related to marketing performance. As a result, the following research themes are identified (see Table 2 for a summary): marketing accountability and credibility, marketing productivity, the interface between marketing and accounting, linking marketing performance to financial performance, the selection of metrics, and the use of marketing metrics in organisations. The paper further identifies those metrics that are most frequently used to link marketing to firm performance. The key metrics are customer satisfaction/customer lifetime value, branding/brand equity, innovation, and market share.

--- Insert Table 2 About Here ---

\section{Developing an integrated framework for measuring marketing performance}

From the literature on marketing performance, it may be seen that a system that incorporates nonfinancial measures into new financial ones is urgently required. Although there is no generic tool for measuring marketing performance, Clark (1999) suggests that better use should be made of the existing measures, rather than devising new ones. Judging from the literature, five dimensions of the measurement of 
marketing performance are the most crucial: market share, customer satisfaction, customer loyalty/retention, brand equity, and innovation.

Given the rapidly rising costs of marketing, marketing managers are under pressure to provide more convincing evidence that "...planned marketing strategies will indeed yield more value for the company and its shareholders..." (Weber 2002, p.705). As a result of increasing pressure to justify marketing expenditure, a better measure of marketing performance that can demonstrate the contribution of marketing to the value of the firm is clearly required (Stewart 2008). A performance measurement model that can provide the link between nonfinancial performance and financial performance is needed. In consequence, the five dimensions of measuring marketing performance should be linked with financial performance, and to this end a synthesised model for measuring marketing performance is proposed (Figure 3). As illustrated in Figure 3, these five constructs (market share, customer satisfaction, customer loyalty/retention, brand equity, and innovation) form the nonfinancial measures, and their joint impact on financial performance should be examined. These joint impacts are shown as lines that link the five constructs in the upper box.

--- Insert Figure 3 About Here ---

\section{CONCLUSIONS AND FUTURE RESEARCH}

The twin aims of this paper are to review the current status of marketing performance studies and to develop a marketing performance measurement model. This study contributes to the marketing literature in several ways. Firstly, by examining a number of marketing performance related terms, the study makes the first attempt to highlight 
some distinctions between these concepts and to draw the inter-relationships between them. Secondly, by incorporating more recent studies, the present research has identified key research themes on the measurement of marketing performance, thus providing a more holistic picture of the current status of marketing performance studies. Thirdly, the study proposes a new integrated Model for Measuring Marketing Performance (MMMP). The model provides an integration of existing measures of marketing performance and new measures of financial performance. Therefore, the model enables marketing professionals to demonstrate the contribution of marketing to firm performance.

Following the proposed theoretical model for measuring marketing success, an immediate need for further research is to apply the model using empirical data obtained from firms. 


\section{REFERENCES}

Aaker, D.A. and Jacobson, R. (1994). The Financial Information Content of Perceived Quality, Journal of Marketing Research.31, 2, pp. 191-201.

Aaker, D.A. and Jacobson, R. (2001). The Value Relevance of Brand Attitude in High-Technology Markets, Journal of Marketing Research. 38, 4, pp. 485493.

Ailawadi, K.L., Lehmann, D.R., and Neslin, S.A. (2003). Revenue Premium as an Outcome Measure of Brand Equity, Journal of Marketing. 67, 4, pp. 1-17.

Aksoy, L., Cooil, B., Groening, C., Keiningham, T.L., and Yalcin, A. (2008). The Long-Term Stock Market Valuation of Customer Satisfaction, Journal of Marketing. 72, 4, pp. 105-122.

Alderson, W. (1948). A Formula for Measuring Productivity in Distribution, Journal of Marketing. 12, April, pp. 442-448.

AMA (1959). Management Report No. 32. Analyzing and Improving Marketing Performance; New York: American Management Association.

Ambler, T. (2000). Marketing Metrics, Business Strategy Review. 11, 2, pp. 59-66.

Ambler, T. (2003). Marketing and the Bottom Line; London: FT: Prentice Hall.

Ambler, T. and Kokkinaki, F. (1997). Measures of Marketing Success, Journal of Marketing Management. 13, 7, pp. 665-678.

Ambler, T. and Roberts, J.H. (2008). Assessing Marketing Performance: Don't Settle for a Silver Metric, Journal of Marketing Management. 24, 7/8, pp. 733-750.

Ambler, T., Kokkinaki, F., and Puntoni, S. (2004). Assessing Marketing Performance: Reasons for Metrics Selection, Journal of Marketing Management. 20, 3/4, pp. 475-498.

Ambler, T., Kokkinaki, F., Puntoni, S., and Riley, D. (2001). Assessing Market Performance: The Current State of Metrics, London Business School, Centre for Marketing Working Paper. 01-903.

Anderson, E.W. and Sullivan, M.W. (1993). The Antecedents and Consequences of Customer Satisfaction for Firms, Marketing Science. 12, 2, pp. 125-143.

Appiah-Adu, K., Fyall, A., and Singh, S. (2001). Marketing Effectiveness and Business Performance in the Financial Services Industry, The Journal of Services Marketing. 15, 1, pp. 18-34.

Barwise, P. and Farley, J.U. (2004). Marketing Metrics: Status of Six Metrics in Five Countries, European Management Journal. 22, 3, pp. 257-262.

Bhargava, M., Dubelaar, C., and Ramaswami, S. (1994). Reconciling Diverse Measures of Performance : A Conceptual Framework and Test of a Methodology, Journal of Business Research. 31, 2-3, pp. 235-246.

Bolton, R.N. (2004). Linking Marketing to Financial Performance and Firm Value, Journal of Marketing. 68, 4, pp. 73-75.

Bonoma, T.V. (1989). Marketing Performance-What Do You Expect?, Harvard Business Review. 67, 5 (September-October), pp. 44-48.

Bonoma, T.V. and Clark, B.H. (1988). Marketing Performance Assessment; Boston: Harvard Business School Press.

Brownlie, D., Saren, M., Wensley, R., and Whittington, R. (eds.) (1999). Rethinking Marketing: Towards Critical Marketing Accountings (1st edn., London: Sage Publications).

Bucklin, L.P. (1978). Productivity in Marketing; Chicago: IL: AMA. 
Bush, A.J., Smart, D., and Nichols, J., Ernest L. (2002). Pursuing the Concept of Marketing Productivity: Introduction to the Jbr Special Issue on Marketing Productivity, Journal of Business Research. 55, 5, pp. 343-347.

Buzzell, R.D. and Chussil, M.J. (1985). Managing for Tomorrow, Sloan Management Review. 26, 4 (Summer), pp. 3-14.

Carson, D. (1990). Some Exploratory Models for Assessing Small Firms' Marketing Performance ( a Qualitative Approach), European Journal of Marketing. 24, 11, pp. 5-49.

Chakravarthy, B.S. (1986). Measuring Strategic Performance, Strategic Management Journal. 7, 5, pp. 437-458.

Clark, B.H. (1999). Marketing Performance Measures: History and Interrelationships, Journal of Marketing Management. 15, pp. 711-732.

Clark, B.H. (2000). Managerial Perception of Marketing Performance: Efficiency, Adaptability, Effectiveness and Satisfaction, Journal of Strategic Marketing. 8, 1, pp. 3-25.

Clark, B.H. and Ambler, T. (2001). Marketing Performance Measurement: Evolution of Research and Practice, International Journal of Business Performance Management. 3, Winter, pp. 231-244.

Connor, P. and Tynan, C. (1999). In Sickness and in Health: Exploring and Redeveloping a Measure of Marketing Effectiveness, Journal of Marketing Management. 15, pp. 733-756.

Cox, R. (1948). The Meaning and Measurement of Productivity in Distribution, Journal of Marketing. 12, April, pp. 433-441.

Davidson, J.H. (1999). Transforming the Value of Company Reports through Marketing Measurement, Journal of Marketing Management. 15, pp. 757-777.

Day, G. and Fahey, L. (1988). Valuing Market Strategies, Journal of Marketing. 52, July, pp. 45-57.

Donthu, N., Hershberger, E., and Osomonbekov, T. (2005). Benchmarking Marketing Productivity Using Data Envelopment Analysis, Journal of Business Research. 58, November, pp. 1474-1482.

Drucker, P. (1974). Management: Task, Responsibilities, Practices; New York: Harper and Row.

Dublinsky, A.J. and Hansen, R.W. (1982). Improving Marketing Productivity: The 80/20 Principle Revisited, California Management Review. 25, 1 (Fall), pp. 96-105.

Duffy, M. (2002), 'Measuring Marketing ROI...Great, but Usually Late', Measuring Marketing Productivity: Linking Marketing to Financial Returns (Dallas, Texas).

Dunn, M.G., Norburn, D., and Birley, S. (1994). The Impact of Organizational Values, Goals, and Climate on Marketing Effectiveness, Journal of Business Research.30, 2, pp. 131-141.

Eccles, R.G. (1991). The Performance Measurement Manifesto, Harvard Business Review. January-February, pp. 131-137.

Farris, P.W., Bendle, N.T., Preifer, P.E., and Reibstein, D.J. (2009). Key Marketing Metrics the 50+ Metrics Every Manager Needs to Know; Harlow: Pearson Education Inc.

Feder, R.A. (1965). How to Measure Marketing Performance, Harvard Business Review. 43, 3 May-June, pp. 132-142. 
Gao, Y. and Bradley, F. (2007), 'A New Marketing Performance Paradigm: A Chinese Study', European Marketing Academy Conference (Kingston Business School, Surrey, UK).

Ghosh, B.C., Schoch, H.P., Kwan, W.W., Kim, T.S., and Yau, O. (1993). Australia and Singapore's Top Performing Organisations: A Comparative Study of Their Marketing Effectiveness, Journal of International Marketing and Marketing Research. 18, 3, pp. 115-139.

Ghosh, B.C., Schoch, H.P., Taylor, D.B., Kwan, W.W., and Kim, T.S. (1994). Top Performing Organizations of Australia, New Zealand and Singapore: A Comparative Study of Their Marketing Effectiveness, Marketing Intelligence and Planning. 12, 7, pp. 39-48.

Herremans, I.M. and Ryans, J.K.J. (1995). The Case for Better Measurement and Reporting of Marketing Performance, Business Horizons. 38, 5 SeptemberOctober, pp. 51-60.

Hogan, J.E., Lehmann, D.R., Merino, M., Srivastava, R.K., and al, e. (2002). Linking Customer Assets to Financial Performance, Journal of Service Research. 5, 1, pp. 26-38.

Homburg, C., Grozdanovic, M., and Klarmann, M. (2007). Responsiveness to Customers and Competitors: The Role of Affective and Cognitive Organizational Systems, Journal of Marketing. 71, 3, pp. 18-38.

Hooley, G.J. and Lynch, J.E. (1985). Marketing Lessons from the Uk's High-Flying Companies, Journal of Marketing Management. 11, 1, pp. 65-74.

Kaplan, R.S. and Norton, D.P. (1992). The Balanced Scorecard- Measures That Drive Performance, Harvard Business Review. 70, January-February, pp. 71-79.

Kolter, P., Gregor, W., and Rodgers, W. (1977). The Marketing Audit Comes of Age, Sloan Management Review. 18, 2, pp. 25-43.

Kotler, P. (1977). From Sales Obsession to Marketing Effectiveness, Harvard Business Review. 55, November-December, pp. 67-75.

Krasnikov, A., Mishra, S., and Orozco, D. (2009). Evaluating the Financial Impact of Branding Using Trademarks: A Framework and Empirical Evidence, Journal of Marketing. 73, 6, pp. 154-166.

Kumar, V. and Petersen, J.A. (2005). Using a Customer-Level Marketing Strategy to Enhance Firm Performance: A Review of Theoretical and Empirical Evidence, Academy of Marketing Science. Journal.33, 4, pp. 504.

Lehmann, D.R. (2004). Metrics for Making Marketing Matter, Journal of Marketing. 68, October, pp. 73-75.

Lovett, M.J. and MacDonald, J.B. (2005). How Does Financial Performance Affect Marketing? Studying the Marketing-Finance Relationship from a Dynamic Perspective, Academy of Marketing Science. Journal. 33, 4, pp. 476.

Luo, X. and Bhattacharya, C.B. (2006). Corporate Social Responsibility, Customer Satisfaction, and Market Value, Journal of Marketing. 70, October, pp. 1-18.

Luo, X. and Donthu, N. (2006a). Marketing's Credibility: A Longitudinal Investigation of Marketing Communication Productivity and Shareholder Value, Journal of Marketing. 70, October, pp. 70-91.

Luo, X. and Donthu, N. (2006b). Marketing's Credibility: A Longitudinal Investigation of Marketing Communication Productivity and Shareholder Value, Journal of Marketing. 70, 4, pp. 70-91.

Marketing Science Institute (2004), Does Marketing Measure Up? Performance Metrics: Practices and Impacts (London Business School, London, England). 
McGrath, A.J. (1993). Commentary: The Management of Marketing Productivity, The Journal of Product and Brand Management. 2, 3, pp. 17-22.

McManus, L. and Guilding, C. (2008). Exploring the Potential of Customer Accounting: A Synthesis of the Accounting and Marketing Literatures, Journal of Marketing Management. 24, 7/8, pp. 771-795.

Mehrotra, S. (1984). How to Measure Marketing Productivity, Journal of Advertising Research. 24, 3, pp. 9-15.

Morgan, N.A. and Rego, L.L. (2009). Brand Portfolio Strategy and Firm Performance, Journal of Marketing. 73, 1, pp. 59-74.

Morgan, N.A., Clark, B.H., and Gooner, R. (2002). Marketing Productivity, Marketing Audits, and Systems for Marketing Performance Assessment: Integrating Multiple Perspectives, Journal of Business Research. 55, 5, pp. 363-375.

Morgan, R.E. and Strong, C.A. (2003). Business Performance and Dimensions of Strategic Orientation, Journal of Business Research. 56, 3, pp. 163-176.

Murphy, J.A. (1997). Marketers Are Productive--They Just Need to Prove It, Marketing News. 31, 18, pp. 4.

Norburn, D., Birley, S., Dunn, M., and Payne, A. (1990). A Four Nation Study of the Relationship between Marketing Effectiveness, Corporate Culture, Corporate Values, and Market Orientation, Journal of International Business Studies. 21, 3 , pp. 451-468.

O'Sullivan, D. (2007). The Measurement of Marketing Performance in Irish Firms, Irish Marketing Review. 19, 1/2, pp. 26-36.

O'Sullivan, D. and Abela, A.V. (2007). Marketing Performance Measurement Ability and Firm Performance, Journal of Marketing. 71, 2, pp. 79-93.

Parker, D.D. (1962). Improved Efficiency and Reduced Cost in Marketing, Journal of Marketing (pre-1986). 26, April, pp. 15-21.

Phillips, P. and Halliday, S.V. (2008). Marketing/Accounting Synergy: A Discussion of Its Potential and Evidence in E-Business Planning, Journal of Marketing Management. 24, 7/8, pp. 751-770.

Rust, R.T. (2002), 'Return on Marketing: Using Customer Equity to Focus Marketing Strategy', Measuring Marketing Productivity: Linking Marketing to Financial Returns (Dallas, Texas).

Rust, R.T., Ambler, T., Carpenter, G.S., Kumar, V., and Srivastava, R.K. (2004). Measuring Marketing Productivity: Current Knowledge and Future Directions, Journal of Marketing. 68, 4, pp. 76-89.

Selnes, F. (1992). Analysing Marketing Profitability: Sales Are a Dangerous CostDriver, European Journal of Marketing. 26, 2, pp. 15-27.

Sevin, C.H. (1965). Marketing Productivity Analysis; New York: McGraw Hill.

Shaw, R. and White, C. (1999). Improving Marketing Accountability through Better Management of the Market Research Process, Journal of Marketing Management. 15, pp. 857-880.

Sheth, J.N. and Sisodia, R.S. (2001). High Performance Marketing, Marketing Management. 10, 3 September/October, pp. 18-23.

Sheth, J.N. and Sisodia, R.S. (2002). Marketing Productivity: Issues and Analysis, Journal of Business Research. 55, 5, pp. 349-362.

Sheth, J.N., Sisodia, R.S., and Sharma, A. (2000). The Antecedents and Consequences of Customer-Centric Marketing, Journal of The Academy of Marketing Science. 28, 1 Winter, pp. 55-66. 
Sidhu, B.K. and Roberts, J.H. (2008). The Marketing Accounting Interface -- Lessons and Limitations, Journal of Marketing Management. 24, 7/8, pp. 669-686.

Skinner, W. (1986). The Productivity Paradox, Harvard Business Review. 64, 4, pp. $55-59$.

Sorescu, A.B. and Spanjol, J. (2008). Innovation's Effect on Firm Value and Risk: Insights from Consumer Packaged Goods, Journal of Marketing. 72, 2, pp. 114-132.

Sriram, S., Balachander, S., and Kalwani, M.U. (2007). Monitoring the Dynamics of Brand Equity Using Store-Level Data, Journal of Marketing. 71, 2, pp. 61-78.

Srivastava, R.K., Shervani, T.A., and Fahey, L. (1998). Market-Based Assets and Shareholder Value: A Framework for Analysis, Journal of Marketing. 62, January, pp. 2-18.

Stewart, D.W. (2009). Marketing Accountability: Linking Marketing Actions to Financial Results, Journal of Business Research. 62, pp. 636-643.

Thomas, M.J. (1984). The Meaning of Marketing Productivity Analysis, Marketing Intelligence \& Planning. 2, 2, pp. 13.

Tuli, K.R. and Bharadwaj, S.G. (2009). Customer Satisfaction and Stock Returns Risk, Journal of Marketing. 73, 6, pp. 184-197.

Verhoef, P.C. and Leeflang, P.S.H. (2009). Understanding the Marketing Department's Influence within the Firm, Journal of Marketing. 73, 2, pp. 1437.

Vorhies, D.W. and Morgan, N.A. (2003). A Configuration Theory Assessment of Marketing Organization Fit with Business Strategy and Its Relationship with Marketing Performance, Journal of Marketing. 67, January, pp. 100-115.

Walker, J.O. and Ruekert, R.W. (1987). Marketing's Role in the Implementation of Business Strategies: A Critical Review and Conceptual Framework, Journal of Marketing. 51, July, pp. 15-33.

Ward, K. (1995). Accounting for Marketing, Financial Management. 73, 5, pp. 20.

Weber, J.A. (2002). Managing the Marketing Budget in a Cost-Constrained Environment, Industrial Marketing Management. 31, 8, pp. 705-717.

Webster, C. (1995). Marketing Culture and Marketing Effectiveness in Service Firms, The Journal of Services Marketing. 9, 2, pp. 6-21.

Welch, D.E. and Welch, L.S. (1996). The Internationalization Process and Networks: A Strategic Management Perspective, Journal of International Marketing. 4, 3, pp. 11-28.

White, J.B., Miles, M.P., and Smith, M.F. (2001). The Interrelationship of Marketing Productivity and Financial Performance for Global Smes, Irish Marketing Review. 14, 1, pp. 55-60.

Wiesel, T., Skiera, B., and Villanueva, J. (2008). Customer Equity: An Integral Part of Financial Reporting, Journal of Marketing. 72, 2, pp. 1-14.

Zhou, K.Z., Yim, C.K., and Tse, D.K. (2005). The Effects of Strategic Orientations on Technology- and Market-Based Breakthrough Innovations, Journal of Marketing. 69, 2, pp. 42-60. 
Table 1: Summary of Definitions of Key Concepts

\begin{tabular}{|c|c|c|}
\hline CONCEPT & DEFINITION & LITERATURE \\
\hline $\begin{array}{l}\text { Marketing } \\
\text { Effectiveness }\end{array}$ & $\begin{array}{l}\text { Doing the right thing. Comparisons of } \\
\text { performance to the goals formulated from market } \\
\text { strategy. }\end{array}$ & $\begin{array}{l}\text { (Appiah-Adu, Fyall, \& Singh } \\
\text { 2001; Clark 2000; Dunn, } \\
\text { Norburn, \& Birley 1994; B C } \\
\text { Ghosh, Schoch, Kwan, Kim, \& } \\
\text { Yau 1993; B. C. Ghosh, Schoch, } \\
\text { Taylor, Kwan, \& Kim 1994; } \\
\text { Kolter, Gregor, \& Rodgers } \\
\text { 1977; N. A. Morgan, Clark, \& } \\
\text { Gooner 2002; Norburn, Birley, } \\
\text { Dunn, \& Payne 1990; Webster } \\
\text { 1995) }\end{array}$ \\
\hline $\begin{array}{l}\text { Marketing } \\
\text { Efficiency }\end{array}$ & $\begin{array}{l}\text { Doing things right. Comparisons of output from } \\
\text { marketing to input of marketing }\end{array}$ & $\begin{array}{l}\text { (Bonoma \& Clark 1988; Clark } \\
\text { 2000; Walker \& Ruekert 1987) }\end{array}$ \\
\hline $\begin{array}{l}\text { Marketing } \\
\text { Productivity }\end{array}$ & $\begin{array}{l}\text { - The ratio of sales or net profits (effect } \\
\text { produced) to marketing costs (energy expended) } \\
\text { for a specific segment of the business } \\
\text { - Effective efficiency. }\end{array}$ & $\begin{array}{l}\text { (Bucklin 1978; Dublinsky \& } \\
\text { Hansen 1982; Feder 1965; Sevin } \\
\text { 1965; Sheth \& Sisodia 2001, } \\
\text { 2002; Skinner 1986; Weber } \\
\text { 2002; White, Miles, \& Smith } \\
\text { 2001) }\end{array}$ \\
\hline $\begin{array}{l}\text { Marketing } \\
\text { Performance }\end{array}$ & $\begin{array}{l}\text { A multidimensional process that includes the } \\
\text { three dimensions of effectiveness, efficiency and } \\
\text { adaptability; the effectiveness and efficiency of } \\
\text { and organisation's marketing activities with } \\
\text { regard to market-related goals, such as revenues, } \\
\text { growth, and market share. }\end{array}$ & $\begin{array}{l}\text { (Ambler \& Kokkinaki 1997; } \\
\text { Ambler, Kokkinaki, \& Puntoni } \\
\text { 2004; Bonoma \& Clark 1988; } \\
\text { Bonoma 1989; Buzzell \& } \\
\text { Chussil 1985; Clark 1999, 2000; } \\
\text { Eccles 1991; Feder 1965; } \\
\text { Herremans \& Ryans 1995; } \\
\text { Kaplan \& Norton 1992; N. A. } \\
\text { Morgan, Clark, \& Gooner 2002; } \\
\text { Welch \& Welch 1996) }\end{array}$ \\
\hline $\begin{array}{l}\text { Marketing } \\
\text { Metrics }\end{array}$ & $\begin{array}{l}\text { The performance indicators that top management } \\
\text { use (or should use) to track and assess the } \\
\text { progress - specifically the marketing performance } \\
\text { - of a business or business unit. }\end{array}$ & $\begin{array}{l}\text { (Marketing Science Institute } \\
\text { 2004) }\end{array}$ \\
\hline
\end{tabular}


Figure 1: Synthesised Inter-relationships among the Key Concepts

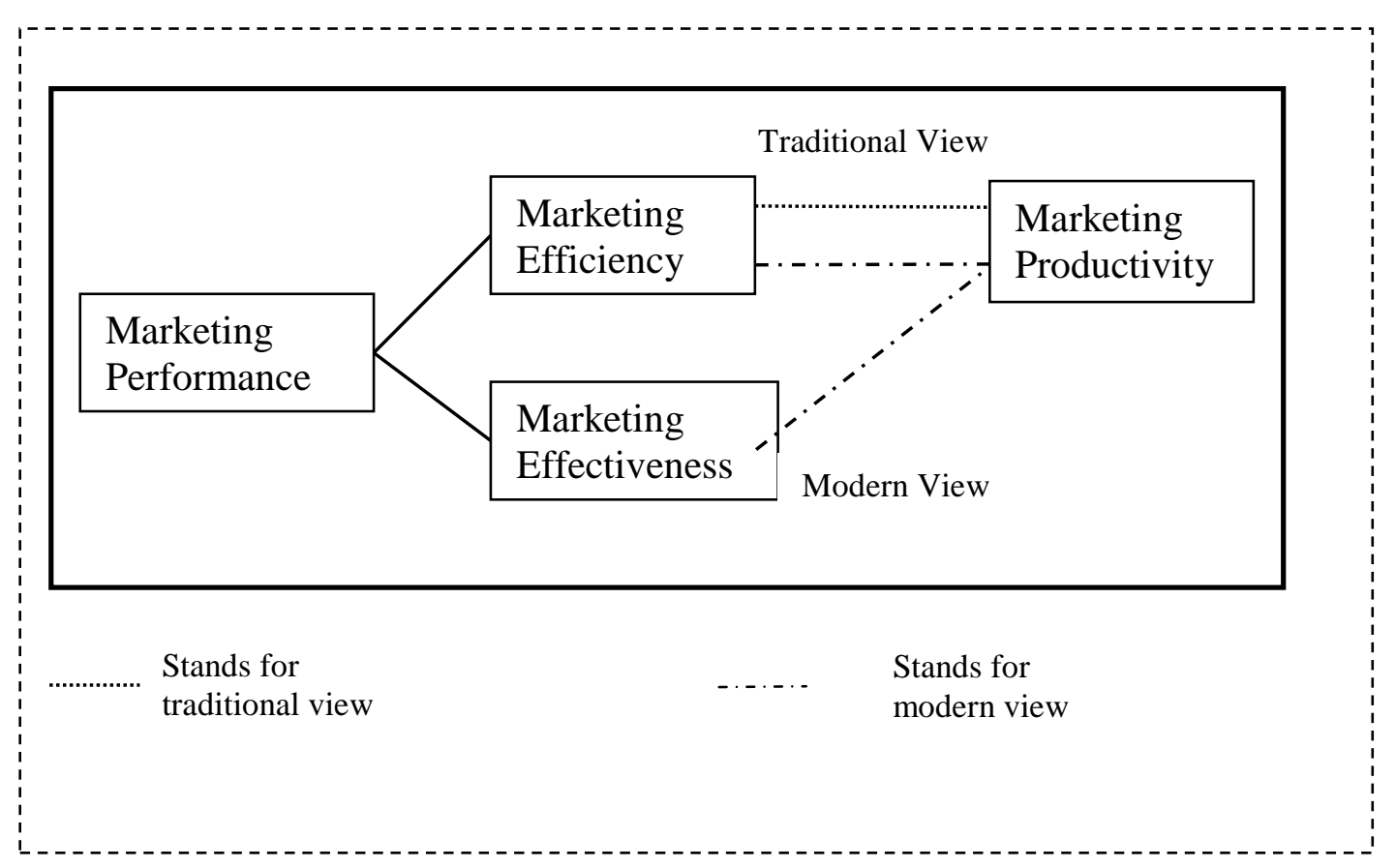


Figure 2: General Trends in the Measurement of Marketing Performance

The Expanding Domain of Marketing Performance

Measures Summarized by Clark (1999, p.714)
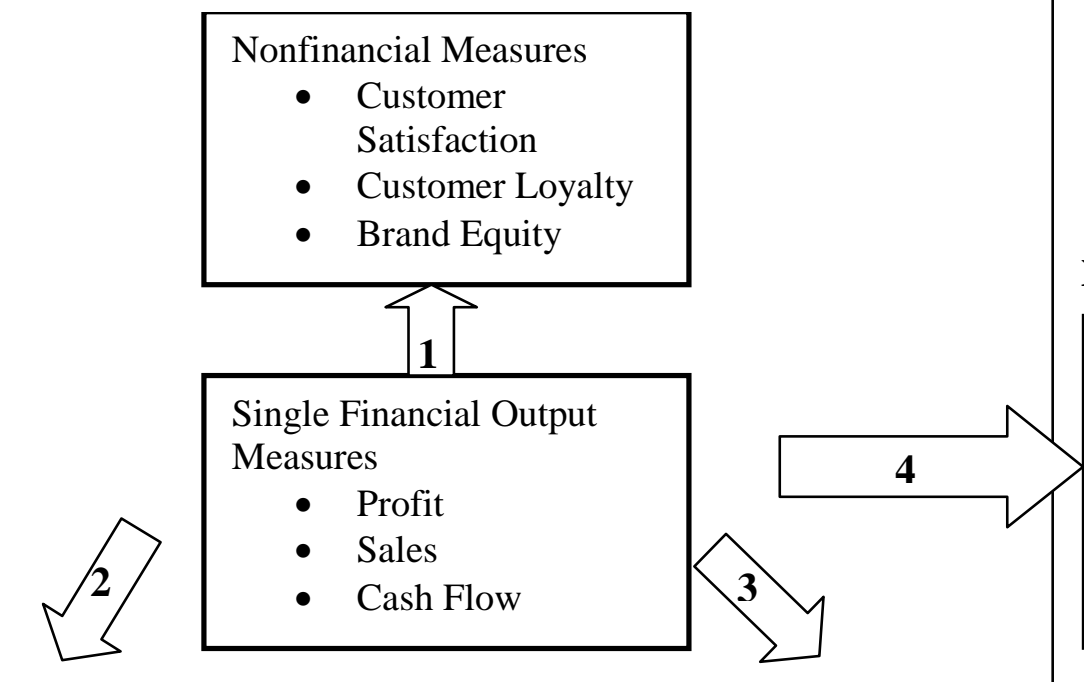

New trend

New

Financial

Output

Measures

- Firm

Value

Input Measures

- Marketing Audit

- Marketing Implementation

- Market Orientation
Multiple Measures

- Marketing Audit

- Efficiency/Effectiveness

- Multivariate Analysis 
Table 2: Categorisation of Studies Related to Marketing Performance

\begin{tabular}{|c|c|}
\hline RESEARCH FIELD & STUDY \\
\hline $\begin{array}{l}\text { Marketing Accountability } \\
\& \text { credibility }\end{array}$ & $\begin{array}{l}\text { (Stewart 2008; Verhoef \& Leeflang 2009) } \\
\text { O'Sullivan and Abela } 2007 \text { Luo and Donthu 2006b) }\end{array}$ \\
\hline $\begin{array}{l}\text { Marketing } \\
\text { Productivity/Marketing } \\
\text { performance Assessment }\end{array}$ & $\begin{array}{l}\text { (Ambler \& Roberts 2008; Bucklin 1978; Bush, Smart, } \\
\text { \& Nichols 2002; Clark 2000; Connor \& Tynan 1999; } \\
\text { Davidson 1999; Day \& Fahey 1988; Donthu, } \\
\text { Hershberger, \& Osomonbekov 2005; Dublinsky \& } \\
\text { Hansen 1982; Duffy 2002; Kotler 1977; McGrath } \\
\text { 1993; Mehrotra 1984; N. A. Morgan, Clark, \& Gooner } \\
\text { 2002; Murphy 1997; Rust 2002; Rust, Ambler, } \\
\text { Carpenter, Kumar, \& Srivastava 2004; Selnes 1992; } \\
\text { Sevin 1965; Sheth, Sisodia, \& Sharma 2000; Sheth \& } \\
\text { Sisodia 2002; Skinner 1986; Thomas 1984; Weber } \\
\text { 2002; White, Miles, \& Smith 2001) }\end{array}$ \\
\hline $\begin{array}{l}\text { Marketing \& Accounting } \\
\text { Interface }\end{array}$ & $\begin{array}{l}\text { (Brownlie, Saren, Wensley, \& Whittington 1999; } \\
\text { McManus \& Guilding 2008; Phillips \& Halliday 2008; } \\
\text { Sidhu \& Roberts 2008; Ward 1995) }\end{array}$ \\
\hline $\begin{array}{l}\text { Linking } \\
\text { performance } \\
\text { performance }\end{array}$ & $\begin{array}{l}\text { (Ambler 2003; Bolton 2004; Gao \& Bradley 2007; } \\
\text { Lovett \& MacDonald 2005; Luo \& Donthu 2006a; } \\
\text { O'Sullivan \& Abela 2007) }\end{array}$ \\
\hline $\begin{array}{l}\text { Marketing Metrics } \\
\text { Practice in organisations }\end{array}$ & (Barwise \& Farley 2004; O'Sullivan 2007) \\
\hline Selection of Metrics & $\begin{array}{l}\text { (Ambler, Kokkinaki, \& Puntoni 2004; Clark 1999; } \\
\text { Farris, Bendle, Preifer, \& Reibstein 2009) }\end{array}$ \\
\hline \multicolumn{2}{|l|}{ Key Metrics Identified: } \\
\hline $\begin{array}{l}\text { Customer satisfaction/ } \\
\text { Customer loyalty/retention } \\
\text { customer lifetime value }\end{array}$ & $\begin{array}{l}\text { (Aksoy, Cooil, Groening, Keiningham, \& Yalẽ } ̊ \ddot{A ̈} \pm n \\
\text { 2008; Anderson \& Sullivan 1993; Hogan, Lehmann, } \\
\text { Merino, Srivastava, \& al 2002; Kumar \& Petersen } \\
\text { 2005; Tuli \& Bharadwaj 2009; Wiesel, Skiera, \& } \\
\text { Villanueva 2008) }\end{array}$ \\
\hline Branding/brand equity & $\begin{array}{l}\text { (Aaker \& Jacobson 1994; Ambler \& Roberts 2008; } \\
\text { Krasnikov, Mishra, \& Orozco 2009; N. A. Morgan \& } \\
\text { Rego 2009; Sriram, Balachander, \& Kalwani 2007) }\end{array}$ \\
\hline Innovation & (Sorescu \& Spanjol 2008; Zhou, Yim, \& Tse 2005) \\
\hline Market share & (Clark 1999; Kaplan \& Norton 1992) \\
\hline
\end{tabular}


Figure 3: Model for Measuring Marketing Performance (MMMP)

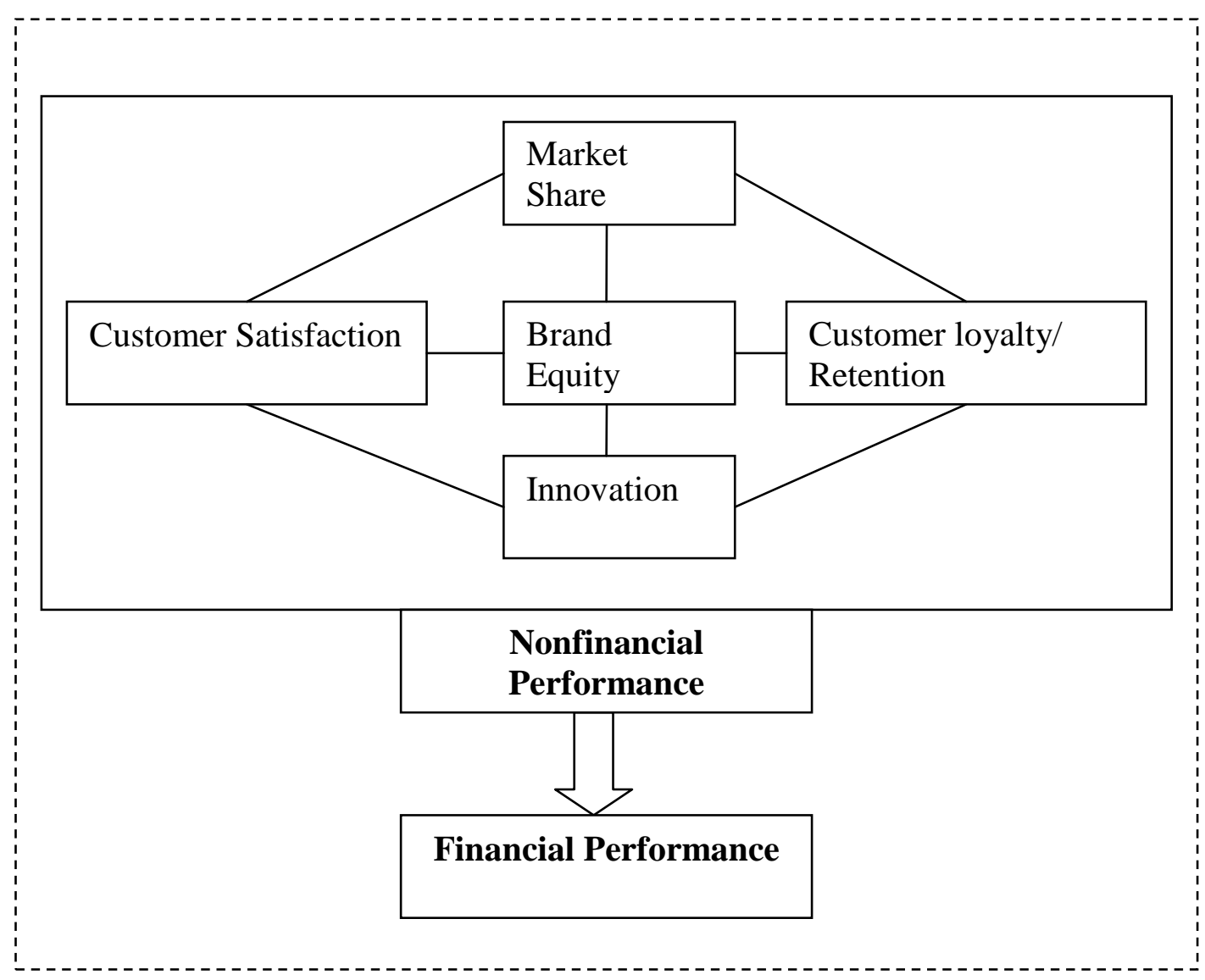

